\title{
Financing Companies using Financial Technology an Exploratory Study
}

\author{
Sadiq Jafar Kadhum Al-Atabi \\ AL-Furat AL-Awsat Technical University - Technical Institute / Diwaniya
}

Sadiq.kadhum2008@yahoo.com

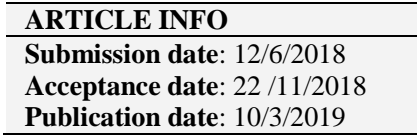

\begin{abstract}
The modern technology to finance investments, of leasing, and the wide attention in the industrialized countries due to their particular flexibility, as well as their low costs often thus making them an alternative to compete with other traditional financing methods. It is noted in this regard that developing countries, especially Arab ones for the most part what relatively late still in the application of this type of financing, companies are leasing is still very low compared with the industrialized countries due to traditional methods control of funding for financial institutions, and non-acceptance risk in new areas of funding, lack of professionalism in the financial and banking field and then dodging relatively active participation in economic development; this study examine the decision to leasing the Iraqi environment as a source of funding for projects to identify extent the desire of the Iraqi projects and their ability to exercise Activity leasing, as well as the desire of the Iraqi banks and their ability to finance the leasing projects, According hypotheses of the study using a model according to the measure " Likert " questionnaire, the first model to the Iraqi projects, as leasing, and was (50) projects, in the face of the second model to the branches of Iraqi banks, as leased, the (40) bank. The study concluded the following results: The desire of the Iraqi projects, and their ability to exercise Activity leasing, as well as a statistically significant relationship between the knowledge of the project of leasing activity and flexible lease process, and pledges to the tenant project against for financing its assets on the one hand, and between the desire of the projects, and their ability to exercise leasing activity on the other.
\end{abstract}

Key words: Lease Decision, Financing

\section{Introduction}

This financial technique appeared in the beginning in some of the activities in the field of aviation, then took accommodates to all economic sectors, it has had a big role in the development of various activities in the United States and countries of the European Community as well as in Japan; so is the basic foundation for all economic growth and then increase the national income and create new jobs and improve the standard of living of the community. This needs to invest money to achieve it is the most important means to achieve, which is one of the most significant developments in the financing of the business sector is the direction of the activities of finance companies toward leasing. The expansion and growth in the use of lease financing is a reflection of the efforts in the field of business finance by finance companies, to finance asset.

(C) Journal of University of Babylon for Pure and Applied Sciences (JUBES) by University of Babylon is licensed under a Creative Commons Attribution 4.0 International License 
To achieve the objectives of the study were to sunlight on this source of funding is important across the three sections, the first research study methodology through the study's importance, objectives, problem and hypotheses, while focusing the second section of the practical frame of the study focused on the analysis of the factors affecting the effectiveness of the decision to leasing as a source of project financing, through a field study projects and the Iraqi banks. The third section of the conclusions and recommendations that have been reached in this study has been devoted.

\section{First section: The methodology of study}

\section{Problem of the study}

It tried to answer the following questions:

1. Does the Iraqi projects have the desire and the ability to exercise leasing activities business?

2. A statement of whether there was a relationship between knowledge and familiarity of the projects of leasing activity and their desire and ability to exercise leasing activity.

3. A statement of whether there was a relationship between Flexible lease process and the desire of the projects and ability to exercise leasing activity.

4. A statement of whether there was a relationship between the pledges of the tenant project in exchange for the financing of its assets and the desire and ability to exercise leasing activity.

5. Do Iraqi banks have the desire and the ability to provide the necessary funding for lease projects.

6.A statement of whether there was a relationship between knowledge and familiarity of Iraqi banks of activity leasing and their desire and ability to provide the funding for lease projects.

\section{The importance of the study}

Leasing represents a new funding put forward at the Iraqi market and when used by the Iraqi projects, It will promote the improvement of the means of production and modernization even keep pace with technological developments, and update the means of production leads to reduced production costs and improve the quality of the products, it also increasing the gross domestic product and compete with imported products and then the positive implications on each economy. A country like Iraq is out of deflation and economic stagnation to the stage in which seeks to the application of an open economic policy and reliance on the free market economy, as well as the reconstruction phase taking place in Iraq and the need of huge foreign capital, all make this country needs to diffeleasing types of investment and financing, which is available in the leasing which leads to open new channels to employ the funds saved in eventually lead to the development of the national economy as well as to contribute in finding more work opportunities in general, and the elimination of unemployment and mitigation and is still the subject of leasing source of funding for projects of concern to researchers in developed countries to this 
day and be out multiple studies and is a result of attention to leases internationally relying on international financial institutions and issued a number of laws and amendments governing the lease and accounting treatment and how to disclose it, issued by international bodies recognized out, as the International Accounting Standard (IAS 17) and the American Financial Accounting Standard (AFAS 13) and British Accounting Standard (SSAP 21).

\section{Objectives of the study:}

The study aims to identifying the role of the leasing in the investment and financing and its importance for all sectors of the economy, it is affecting the desire of those sectors in the studied extensively and can exercise leasing, and the possibility of its application between the projects and the Iraqi banks. As well as to recognize the key components of the environment that encourages the development of leasing sector, including:

Recent legislation in most Arab countries, and limited to explanatory leaflets for regulating the activity of leasing in others such as Syria, for example ,and the lack of it in other countries, including Iraq. Limited deal with leasing being a modern decision on global financial arena in general, and Arab states such as Iraq, in particular. As well as stand on the work mechanism of this new funding pattern and the study results relating to its financial terms, and their impact on the budget of companies and economic terms, and its impact on decision-making process in buying or financing the businesses that contribute to the achievement of the balance between liquidity and profit resulting from the investment, which is the standard to measure investment performance in achieving its objectives.

\section{Hypotheses of the study}

In light of the study the problem of leasing dimensions, are hypotheses in two main parts, namely:

i. assumptions relating to the tenant Iraqi projects, consists of the following assumptions:

- The first hypothesis: the tenant projects have the desire and the ability to exercise leasing activity.

- The second hypothesis: familiar of the project and his knowledge of leasing activity lead to his desire and ability to exercise leasing activity.

- The third hypothesis: flexibility leasing process lead to the desire of the projects and their ability to exercise leasing activity.

- The fourth hypothesis: pledges of tenant project in exchange for finance assets lead to his desire and ability to exercise leasing activity.

ii. The assumptions relating to Iraqi banks, consists of the following assumptions:

- The first hypothesis: Banks are willing and able to provide funding for leasing projects. 
- The second assumption: : familiar of the bank and his knowledge of leasing activity lead to the desire and ability to provide funding for projects leasing.

- The third hypothesis: flexibility leasing process lead to the desire of the Iraqi banks and their ability to provide funding for leasing projects.

- The fourth hypothesis: the procedures and banking laws lead to the desire of the Iraqi banks and their ability to provide funding for leasing projects.

- The fifth hypothesis: The project pledges to the Bank in the financing of assets lead to the desire of the Iraqi banks and their ability to provide funding for leasing projects.

\section{Study population}

It was selected a sample of Iraqi projects, acting as a lessee, amount (50) project, and a sample of Iraqi banks as lessor, amount (40) banks, and both samples represent the axis of the poles of leasing process. The study relied on a descriptive and analytical approach based on field study through questionnaire faced by the researcher to Iraqi projects, and another to the Iraqi banks, in order to achieve the objectives of the study.

Researcher presented two models questionnaire, a questionnaire (1) and (2), has been directing the questionnaire model (1) to the lessee of the Iraqi projects (Annex 1), while the questionnaire model (2) face to the lessor of the Iraqi banks (Appendix 2). The questionnaire model (1) contained (6) questions (one question represents dependent variable, the five questions represents independent variables), the dependent variable measures the desire of Iraqi projects and their ability to exercise leasing activity, as represented independent variables of factors influencing the willingness and their ability of these projects to exercise leasing activity, while the questionnaire model (2) contained the dependent variable, which measures the willingness of Iraqi banks and their ability to finance leased projects, as well as the independent variables that represent factors affecting the willingness and ability of those banks to provide financing leased projects, it has reached ten questions (one question is dependent variable, while nine questions represent independent variables). The researcher used a quintet (Likert) scale when answering every question contents of a typical questionnaire. The study sample was tested within the projects registered in the Chamber of Commerce of Diwaniyah, the Iraqi banks located in the provinces of Diwaniyah, Najaf, Babil, Karbala and Muthanna. The researcher respondent's managers, accountants and financial controllers in the projects and the Iraqi banks chose because they have sufficient capability to cover the subject by virtue of accumulated experience and high specialization they have enjoyed.

\section{Study variables}

The study included two separate dependent variables, one according to the questionnaire model (1) for leasing projects and was measured with one question, five answers according to the Likert scale. The answers are (fully agree, agree, neutral, disagree, disagree at all), These responses have values $(1,2,3,4,5)$, respectively, as 
well as for the other dependent variable according to the questionnaire sample (2) directed to branches of Iraqi banks. The results of the questionnaire were analyzed using SPSS. The methods used were many tests such as stability and honesty testing, data revision testing, repetition tables, total or mean calculation of each variable, standard deviation $\sigma$, correlation R, The coefficient of determination R2, T test, and ANOVA.

The researcher can explain the independent variables of each model as follows:

A) questionnaire Sample (1): The model is linked to leased projects. The model included three independent variables as follows : 1: Study the project knowledge of the activity of leasing: This variable aims to identify the knowledge of the tenant project of leasing's activity as a source of funding and possess the Knowledge of all aspects related to this activity .

2: The flexibility of the lease process: is the terms of the lease contract leading to the connection of installments paid on the lease of the asset in conjunction with the proceeds of the project from cash flows resulting from the use of that asset? Or is the flexibility of the leasing's process achieved by the tenant's project ability to cancel the lease at any time when the need arises from using the asset?

3: The Tenant Project Commitments for the financing of its assets: This means reducing the collateral and commitments when leasing assets compared to the situation of buying assets through borrowing. To measure this variable, a number of questions have been formulated of which :Are the legal procedures required in the lease are simple compared to borrowing from foreclosure, guarantees and other? Or are the undertakings made by the lessee to the lessor will be few because the ownership of the original remains for the lessor.

B) questionnaire Sample (2): The model is related to branches of Iraqi commercial and specialized banks, which finance leasing projects. The model included four independent variables as follows:

1)Study the Iraqi banks knowledge of the activity of leasing: The purpose of this variable is to identify the extent to which the leased bank is aware of the leasing activity as a source of financing, possessing sufficient knowledge of all aspects related to this activity, and its desire and ability to provide the necessary financing for the leased projects.

2) The flexibility of the lease process: means, Are the terms of the tenancy contract that leads to the lessor's ability to choose the tenant whose needs are consistent with the nature of the service provided to him as a result of the close relationship between them? Or is the flexibility of the leasing process to ensure that the value of the asset is invested up to the end of its economic life by contracting the leasing again or by looking for better leasing opportunities? Or that the terms of the lease contract lead to the preservation of the leased assets by the tenant being charged with the risk of possession of the asset and maintenance and insurance costs

3) Banking procedures and laws: This variable shows the extent of consistency of banking rules and principles with the banks of the work of the activities of leasing; To measure this variable was formulated a number of questions, including: Are there no 
banking obstacles when the practice of the Iraqi banks lease activity? Or does the bank have the possibility of establishing specialized companies affiliated with it and enjoy incentives and exemptions through the investment law? Or do banks have the ability to exercise the activity of land and real estate?

4) Project commitments to the Bank in the financing of assets: The provision of guarantees and pledges when financing projects for the leasing of assets compared to lending guarantees, In order to measure this variable, a number of questions have been formulated, including: Does the lessor retain the ownership of the asset and the possibility of its recovery when the tenant breaches the terms of the contract and fails to pay the remaining payments? Or the pledges are the ability of the lessor to seize the assets as the legal owner of them, which leads to the surest guarantee of the lessor in collecting the payments made by the lessee.

\section{The second sector : projects and leasing decision}

The attempt to maximize profit in a market where supply and demand forces do not equate in a technical way, in which prices do not distribute income and allocate resources, are dominated by monopolistic organizations competing for the production of new goods[1] the use of modern productive art and struggling to control primary resources and other factors of production. The Organizer will review two issues on an ongoing basis: [2]

1- Determine the economic age of the project and the proportion between its size and market needs, and the possibility of establishing new units, modification or cancellation of existing units or, in other words, it must review the structure of the project and ways of cooperation and coordination with other projects.

2- To determine the maximum possible efficiency of the available factors of production, taking into account any technical progress that may affect the quality of goods and services, replenish its productive assets or replace them with other more advanced assets using the discoveries of modern scientific innovations.

The first issue is at the heart of the study of the economic focus and its legal, regulatory and contractual instruments, which have received a great deal of attention[3] .

The second issue is the study of the art of management and investment planning in the project, especially the definition of capital expenditure, which represents expenditures that achieve gains over a period of time more than a year [4] which differ from the operating expenses that achieve gains during the period not exceeding the year [5]

In spite of the multiplicity of capital expenditure patterns, the decisions related to it can generally be classified into three groups[6]

1)Decisions related to the addition of new assets to increase the production capacity of the project.

2)Decisions involve renewing fixed assets consumed to maintain the cur leasing level of production. 
3)Decisions involve replacement of new machines and equipment and advanced technology replaced another less advanced to reduce production costs.

Once the regulator has made the appropriate decision and determines the asset to be acquired, the next step is to look for funding, ie, to determine how to get the funds needed to finance the investment. The project derives its funding from internal sources, such as capital and reserves of various types, which are deducted from net distributable profits, or from external sources such as borrowing from financial institutions or issuing public subscription bonds as well as commercial credit [7]

Perhaps the most important feature of external financing means that it receives the project to which it has a fixed burden, as it must meet the installments of debt when the deadlines and pay the additional benefits due to them, whether profit or loss[8] .

The sources of internal finance, although the least sources of funds, are a burden on the project because they do not impose firm obligations on them. Financial management specialists consider them the most expensive sources of finance because they are the cost of the alternative. The retained earnings can be distributed to the shareholders and can be invested in Other alternative fields It is obvious that they will invest them in the best areas that give a higher rate of return than others [9]

The ability to borrow from financial institutions depends in turn on various factors affecting them and limiting their scope in one way or another, such as the amount of capital, the size of the collateral provided by the project to lenders, the degree of risk and profitability associated with each type of loan, the economic conditions and monetary and fiscal policies imposed by the authorities The public offering of bonds for public subscription is subject to complex formal and substantive conditions, and is a means available only to a particular form of trading company. [10]

Commercial credit, in turn, is a source of external financing, as many projects can obtain it when no financial institution is willing to lend it the necessary funds. This depends on various factors such as the seller's position and desire to dispose of his commodity inventory[11], The nature of the commodity, the geographical location of the customers and the extent of the business boom), which is a high-cost credit, especially when compared to bank credit. The seller may hesitate to grant it in many cases because it may be at risk of bankruptcy by the buyer after receiving the goods and then for the competition of the grooms. [7]

It may happen that the project already exhausts all traditional internal and external financing means and must nevertheless "capture real assets that exist at a specific time and generate real production services during this time period", so it should look for new ways of financing.[12]

US projects have found in this desirable means. This new financing process is carried out in a project that wants to acquire a specific production asset that determines the technical specifications of the asset [13] . It may choose it by itself and discuss the conditions of its purchase with the seller in many cases. Agrees with a specialized financing institution to purchase it and to lease from it a certain period of time, usually the economic life of that productive asset, for a periodic fee covering the purchase price, transaction costs and interest, and a reasonable profit margin for the leased financial institution[14]. Lease period The beneficiary project has the option of 
returning the asset to the financial institution or requesting renewal of the contract for another period at a lower cost or buying the asset from the financial institution and paying the residual value[15]. Does not consume financially from the invested capital ", since the contract includes a promise of sale binding on the leased financial institution to the benefit of the tenant beneficiary, thus relying on the" lease contract [16]

\section{The third section: practical side}

Factors affecting the efficiency of the leasing process as a source of financing projects through the field study:

The objective of the study is to study the factors influencing the desire of the Iraqi leased enterprises and their ability to practice the leasing activity, as well as the desire of the Iraqi banks and their ability to provide the necessary financing for the leased projects. The practical framework of these factors was analyzed by the following points:

A) Data analysis and testing of study hypotheses associated with leased projects.

B) Data analysis and testing of study hypotheses related to Iraqi banks.

C) Data analysis and testing of study hypotheses associated with leased projects.

1) The reliability of the questionnaire (coefficient (0.992) which is also very high

Table (1):Test the consistency and honesty questionnaire questions (1)

\begin{tabular}{|c|c|c|}
\hline Number of items & Honesty & Cronbach Alpha coefficient \\
\hline 6. & 0.992 & 0.984 \\
\hline
\end{tabular}

1) was calculated by calculating the value of the Kronbach coefficient, as well as the validity test of the data shown in Table (1). The table shows that the value of the Alpha Kronbach (0.984) is high, which means the high credibility of the data from the opposite of the sample results on the study population, and the number of elements (6) represents the total of the questionnaire questions (1).

The reliability coefficient was calculated by calculating the root of the stability 2) Data review test: The questionnaire questions for the dependent variable and the independent variables (according to their sequence in the questionnaire form 1 in Annex 1) are verified by reviewing (by extracting the value of the Cronbach parameter at the deletion of the statement) shown in Table (2) The coefficient of alpha kronbach when deleting the expression (for) the value of the alpha coefficient Kronbach total), this indicates that this phrase weakens the scale and that delete it leads to increased stability, as the table shows that all (alpha coefficient values Kronbach when the phrase is deleted) Alfa Cronbach total (0.984) except question (2) The second question of the second variable) "the possibility of canceling the leasing at any time when the need to use the asset, which is the value of alpha Kronbach 
(0.989), and this has no effect as long as the difference is very slight, and the coefficient Alpha Kronbach total is high, Question questionnaire questions were valid (1).

Table (2)Revision questions questionnaire form (1)

\begin{tabular}{|c|c|c|}
\hline \multirow{2}{*}{ The variable } & $\begin{array}{c}\text { The question in } \\
\text { sequence. } \\
\text { Questionnaire (1) }\end{array}$ & Alkronbakh when deleting \\
\hline \multirow{2}{*}{ Disciple } & 1 & 0.984 \\
\hline \multirow{5}{*}{ Variables } & 2 & 0.983 \\
\cline { 2 - 3 } & 3 & 0.983 \\
\cline { 2 - 3 } Independent & 4 & 0.989 \\
\cline { 2 - 3 } & 5 & 0.983 \\
\hline
\end{tabular}

\section{3- Data analysis and hypothesis testing:}

* Test the first hypothesis related to the dependent variable: "For Iraqi projects as a tenant, the desire and ability to engage in leasing activity."

The variable was measured by one question, which was directed to the directors and financial officials in each project. The number of respondents to fill out the survey questionnaire (1), (79) respondents from (100) questionnaire distributed to (50) Statistical analysis of the dependent variable

The results of Table (3) show that the directors and financial officials of Iraqi enterprises have.

The respondents' responses showed that the most frequent answers were (fully agree) and 31 recurrences (39.2\%). The mean of the variable question (4.15) with a standard deviation of 0.802 ; this means accepting the hypothesis of the study of the desire and ability of Iraqi enterprises to practice the leasing activity. 
Table (3):Respondents answer About the interest the project and his ability to exercise active leasing Direction of :

\begin{tabular}{|c|c|c|c|c|c|c|c|c|}
\hline \multirow{3}{*}{$\begin{array}{c}\text { Dependent variable } \\
\text { (The project's desire } \\
\text { and ability to } \\
\text { exercise active } \\
\text { leasing) }\end{array}$} & $\begin{array}{l}\text { Strongly } \\
\text { Aoree }\end{array}$ & Agree & Neutral & Disagree & $\begin{array}{l}\text { Strongly } \\
\text { Disaoree }\end{array}$ & \multirow{3}{*}{$\begin{array}{c}\text { Weighted } \\
\text { average }\end{array}$} & \multirow[b]{3}{*}{$\begin{array}{l}\text { Standard } \\
\text { deviation }\end{array}$} & \multirow[b]{3}{*}{ Direction } \\
\hline & Iterations & Iterations & Iterations & Iterations & Iterations & & & \\
\hline & $\%$ & $\%$ & $\%$ & $\%$ & $\%$ & & & \\
\hline $\begin{array}{l}1 \text { have your } \\
\text { willingness and } \\
\text { ability to exercise } \\
\text { active leasing. }\end{array}$ & 39.2 & 38 & 21.5 & 1.3 & - & & & \\
\hline
\end{tabular}

Data analysis and testing of independent variables:

* data analysis

1: Familiarity with the project and its knowledge of leasing activity: This variable was measured by one question addressed to the study community. Table (4) shows the approval of Iraqi project managers and financial officials to have sufficient know-how and knowledge of the leasing activity as the source of funding for the projects according to the weighted average. The responses of the respondents showed that the most frequent answers are (36) (45.6\%). The mean of the variable (3.65) was calculated by a standard deviation of 0.848 . 
Journal of University of Babylon, Pure and Applied Sciences, Vol.(27), No.(1): 2019

Table (4) Respondents answer About project aware and actively include him leasing Direction of

\begin{tabular}{|c|c|c|c|c|c|c|c|c|}
\hline \multirow{3}{*}{$\begin{array}{l}\text { The independent } \\
\text { variable (familiar } \\
\text { with the project and } \\
\text { actively include him } \\
\text { leasing). }\end{array}$} & $\begin{array}{l}\text { Strongly } \\
\text { Agree }\end{array}$ & Agree & Neutral & Disagree & $\begin{array}{l}\text { Strongly } \\
\text { Disagree }\end{array}$ & \multirow{3}{*}{ mean } & \multirow{3}{*}{$\begin{array}{l}\text { Stander } \\
\text { division }\end{array}$} & \multirow{3}{*}{ Direction } \\
\hline & Iterations & Iterations & $\begin{array}{c}\text { Iteration } \\
\mathrm{s}\end{array}$ & Iterations & Iterations & & & \\
\hline & $\%$ & $\%$ & $\%$ & $\%$ & $\%$ & & & \\
\hline \multirow[b]{2}{*}{$\begin{array}{l}\text { 1)being a Manager } \\
\text { or responsible } \\
\text { financially for the } \\
\text { project, you have } \\
\text { the expertise and } \\
\text { knowledge of } \\
\text { caffeine in all } \\
\text { aspects related to } \\
\text { the activity of } \\
\text { leasing as a } \\
\text { funding source. }\end{array}$} & 11. & 36 & 26 & 5. & 1. & \multirow[t]{2}{*}{3.65} & \multirow[t]{2}{*}{0.848} & \\
\hline & 13.9 & 45.6 & 32.9 & 6.3 & 1.3 & & & Ok \\
\hline
\end{tabular}




\begin{tabular}{|c|c|c|c|c|c|c|c|c|}
\hline \multirow{3}{*}{$\begin{array}{l}\text { Independent variable v } \\
\text { (flexible lease process) }\end{array}$} & $\begin{array}{l}\text { Strongly } \\
\text { Agree }\end{array}$ & Agree & Neutral & Disagree & $\begin{array}{l}\text { Strongly } \\
\text { Disagree }\end{array}$ & \multirow{3}{*}{ mean } & \multirow[b]{3}{*}{$\begin{array}{l}\text { Standard } \\
\text { deviation }\end{array}$} & \multirow{3}{*}{ Direction } \\
\hline & Iterations & Iterations & Iterations & Iterations & Iterations & & & \\
\hline & $\%$ & $\%$ & $\%$ & $\%$ & $\%$ & & & \\
\hline \multirow{4}{*}{$\begin{array}{c}1 \text { possibility of cancelling } \\
\text { the lease at any time } \\
\text { when you removed the } \\
\text { need for the use of the } \\
\text { asset. }\end{array}$} & 12. & 38 & 23 & 4. & 2. & & & \\
\hline & 15.2 & 48.1 & 29.1 & 5.1 & 2.5 & & & \\
\hline & .17 & 15. & .13 & 16. & 18. & \multirow{2}{*}{2.96} & \multirow{2}{*}{1.480} & \multirow{2}{*}{ Neutral } \\
\hline & 21.5 & 19.0 & 16.4 & 20.2 & 22.7 & & & \\
\hline
\end{tabular}

2)The flexibility of the leasing process: This variable was measured by two factors that represented two face-to-face questions to the study population. The results of the statistical analysis in Table (5) showed the approval of the respondents to the factor and the neutrality of another factor, which have an effect on the flexibility of the leasing process by means of the weighted average. The arithmetical average of the respondents' replies about the possibility of canceling the leasing at any time when the need for the use of the asset (3.69) with a standard deviation (0.885). The reason for this, according to the researcher's opinion, is the nature of dealing in the market used by Iraqi projects, while the responses of the study society towards neutrality were an effective factor in the flexibility of the leasing process In conjunction ( 2.96) with a standard deviation of (1.480). This is due to the researcher's view of the delay in cash flows resulting from the use of the asset due to the failure of government officials in local governments To fulfill their obligations to the entrepreneurs, because most of the work of the projects at the cur leasing stage is one of the parties.

\section{Table (5): Direction of the sample answers About flexible leasing process}

3: The Tenant Project Commitments for Financing its Assets: This variable was measured by two factors that were represented by two questions face to face with the study society. Table (6) shows the approval of Iraqi leased projects due to the lack of guarantees provided by the lessee to the lessor because the ownership of the asset is left to the lessee by the weighted average of the respondents' answers with an average of (4.05) with a standard de aviation (0.918) (3.96) with a standard deviation (0.953). According to the owners of the projects, most leasing the equipment with their employees leads to the simplicity of the procedure $\mathrm{T}$. 
Table (6):Direction of the sample answers About project funding tenant pledges its assets :

\begin{tabular}{|c|c|c|c|c|c|c|c|c|}
\hline \multirow{3}{*}{$\begin{array}{l}\text { Independent variable vi } \\
\text { (leased assets funded } \\
\text { projects commitments) }\end{array}$} & $\begin{array}{l}\text { Strongly } \\
\text { Agree }\end{array}$ & Agree & Neutral & Disagree & Strongly & \multirow{3}{*}{ mean } & \multirow{3}{*}{$\begin{array}{l}\text { Standard } \\
\text { deviation }\end{array}$} & \multirow{3}{*}{ Direction } \\
\hline & Iterations & Iterations & Iterations & Iterations & Iterations & & & \\
\hline & $\%$ & $\%$ & $\%$ & $\%$ & $\%$ & & & \\
\hline \multirow{2}{*}{$\begin{array}{l}\text { 1) lack of guarantees } \\
\text { provided by the tenant to } \\
\text { the landlord because the } \\
\text { pleasing property of the } \\
\text { lessor's survival. }\end{array}$} & 26 & 38 & 10. & 3. & 2. & \multirow[t]{3}{*}{4.05} & \multirow{3}{*}{0.918} & \multirow{3}{*}{ Ok } \\
\hline & 32.9 & 48.1 & 12.7 & 3.8 & 2.5 & & & \\
\hline \multirow{2}{*}{$\begin{array}{l}\text { 2) required legal } \\
\text { procedures simply } \\
\text { leasing compared to } \\
\text { what is required to } \\
\text { borrow from mortgage } \\
\text { bonds or other. }\end{array}$} & .20 & 46 & .7 & 2. & 4. & & & \\
\hline & 25.3 & 58.2 & 8.9 & 2.5 & 5.1 & 3.96 & 0.953 & Ok \\
\hline
\end{tabular}

*Test the second hypothesis: "There is a statistically significant relationship between the knowledge of the project and his knowledge of the leasing activity and his desire and ability to engage in the activity of leasing."

In order to test the validity of this hypothesis, the correlation coefficient and the coefficient of selection were measured between the independent variable and the dependent variable. The results in Table (7) show that the project's knowledge and knowledge of the leasing activity have a strong relationship with its desire and ability to engage in the leasing activity, (57.9\%), while the coefficient of determination (R2) (57.6\%), which indicates that the independent variable can explain the equivalent of $(57.6 \%)$ of the change in the willingness of enterprises and their ability to practice the leasing activity.

The table also shows that the value of the regression coefficient for the project's knowledge and knowledge of the leasing activity is (0.718). This means that the change of one unit in the project knowledge and knowledge of the leasing activity will result in a change in the project's desire and ability to exercise the leasing activity by (0.718) (2.625) and at a significant level (1\%) with the effect of statistical significance of the project's knowledge and knowledge of the leasing activity on the project's desire and ability to practice the leasing activity. The hypothesis of the study was accepted by the existence of a statistically significant relationship between the knowledge of the project and his knowledge of the leasing activity and his desire and 
ability to practice the leasing activity. The results of these tests confirm their statistical acceptance. The computation (104.544) was greater than the table of 6.97 at a significant level (1) \%) And freedom degree (1/77).

The table (7): The results link relationships and regression according to respondents answer About the relationship of project aware and actively include him leasing with his desire and ability to exercise active leasing

\begin{tabular}{|c|c|c|c|c|c|c|}
\hline \multirow{2}{*}{$\begin{array}{c}\text { Regression } \\
\text { coefficient }\end{array}$} & \multicolumn{2}{|c|}{ Test $t$} & \multirow{2}{*}{$R 2$} & \multicolumn{2}{c|}{$R$} & \multicolumn{2}{c|}{ Test F } \\
\cline { 2 - 6 } & $\begin{array}{c}\text { Calculated } \\
*\end{array}$ & Crosstab & & & $\begin{array}{c}\text { Calculated } \\
*\end{array}$ & Crosstab \\
\hline 0.718 & 10.225 & 2.640 & $57.6 \%$ & $75.9 \%$ & 104.544 & 6.97 \\
\hline
\end{tabular}

\section{* The moral level $1 \%$}

Test the third hypothesis "There is a statistically significant relationship between the flexibility of the leasing process and the willingness of the enterprises and their ability to engage in the leasing activity."

In order to test the validity of this hypothesis, the correlation coefficient and the coefficient of selection were measured between the independent variable and the dependent variable.

The results in Table (8) show that the flexibility of the lease process is strongly related to the project's desire and ability to engage in the leasing activity as indicated by $\mathrm{R}$ (55.1) (30.4\%), ie, the independent variable has a weak effect on the dependent variable. This is confirmed by the data review test because one of the questions of this variable was increased (the value of the alpha coefficient of Cronbach when deleting the expression) (The value of the total Cronbach alpha coefficient) $(6,640)$. The value of ( $t$ ) calculated for the regression coefficient value of this variable $(5,795)$, which is greater than the scale (2.640) and at a significant level (1\%), has a statistically significant effect of the flexibility of the lease on the project's desire and ability to practice The study hypothesis was accepted with a statistically significant relationship between the elasticity of the leasing process and the project's desire and ability to practice the leasing activity. The results of this study confirm the statistical acceptance of F; the calculated (33.580) was greater than the tabular (6.97) (1\%) and freedom degree $(1 / 77)$. 
Table (8): The results link relationships and regression according to respondents answer About the relationship of the flexibility of the process of lease with the desire and ability to exercise active projects leasing

\begin{tabular}{|c|c|c|c|c|c|c|}
\hline $\begin{array}{c}\text { Regression } \\
\text { coefficient }\end{array}$ & \multicolumn{2}{|c|}{ Test $t$} & \multirow{2}{|c|}{$R 2$} & & \multicolumn{2}{c|}{ Test F } \\
\cline { 2 - 6 } & $\begin{array}{c}\text { Calculated } \\
*\end{array}$ & Crosstab & & & $\begin{array}{c}\text { Calculated } \\
*\end{array}$ & Crosstab \\
\hline 0.460 & 5.795 & 2.640 & $30.4 \%$ & $55.1 \%$ & 33.580 & 6.97 \\
\hline
\end{tabular}

\section{* The moral level 1\%}

Test the fourth hypothesis:"There is a statistically significant relationship between the undertakings of the tenant project against the financing of its assets, its desire and its ability to engage in the leasing activity."

In order to test the validity of this hypothesis, the correlation coefficient and the determining factor were measured between the independent variable and the dependent variable. The results in Table (9) show that the commitments of the leased project against the financing of its assets have a strong relationship with the project's desire and ability to engage in the leasing activity, (77.3\%), while the coefficient of determination (R2) (59.8\%), meaning that the independent variable has a strong influence on the dependent variable. The value of the regression coefficient for the leased project's projects versus the financing of its assets is estimated at 0.657 . The value of $(\mathrm{t})$ calculated for the regression coefficient value of this variable is 10.707 , which is larger than the scale of 2.640 and at a significant level (1\%). The project was approved for the financing of its assets based on the project's desire and ability to practice the leasing activity. Thus, the hypothesis of the study was accepted with a statistically significant relation between the project's undertakings versus the financing of its assets and the project's desire and ability to practice the leasing activity. The calculated (114.643) was the highest Of Tabulated (6.97) at the abstract level $(1 \%)$ and the degree of freedom (1/77).

Table (9): The results link relationships and regression according to respondents answer About the relationship of project commitments with assets funded tenant projects and their ability to exercise active leasing :

\begin{tabular}{|c|c|c|c|c|c|c|}
\hline \multirow{2}{*}{$\begin{array}{l}\text { Regression } \\
\text { coefficient }\end{array}$} & \multicolumn{2}{|c|}{ Test $t$} & \multirow[t]{2}{*}{$R 2$} & \multirow[t]{2}{*}{$R$} & \multicolumn{2}{|c|}{ Test $F$} \\
\hline & $\begin{array}{c}\text { Calculated } \\
*\end{array}$ & Crosstab & & & $\begin{array}{c}\text { Calculated } \\
*\end{array}$ & Crosstab \\
\hline 0.657 & 10.707 & 2.640 & $59.8 \%$ & $77.3 \%$ & 114.643 & 6.97 \\
\hline
\end{tabular}

* The moral level $1 \%$ 
B) Data analysis and testing of study hypotheses related to leased banks: 1) The reliability and reliability of vocabulary tests: The reliability of the questions of the questionnaire model (2) was calculated by calculating the value of the alphacronbach coefficient, as well as the validity test of the data shown in Table (10). Table (10) shows that the value of the Alpha Kronbach coefficient for the questions of the questionnaire form (2) is 0.995 . It is very high, which means the high credibility of the data from the opposite of the sample results on the study population. The reliability coefficient was calculated by calculating the root of the stability coefficient (0.997) which is also very high.

Table (10):Test the consistency and honesty questionnaire questions (2)

\begin{tabular}{|r|l|l|}
\hline Number of items & Honesty & Cronbach Alpha coefficient \\
\hline 24 & 0.997 & 0.995 \\
\hline
\end{tabular}

2) Data review test: The questionnaire questions for the dependent variable and the independent variables (according to their sequence in the questionnaire form 2 in Annex IV) are verified by reviewing (by extracting the value of the Cronbach alpha when deleting the statement) That all the values of the Alpha Cronbach parameter when the term (not more than) the total alpha-Cronbach coefficient (0.995) is deleted. This confirms the validity of the questions of the questionnaire form 2 and validates them.

Table (11): Revision questions questionnaire form (2)

\begin{tabular}{|c|c|c|c|c|c|}
\hline $\begin{array}{l}\text { The } \\
\text { variable }\end{array}$ & $\begin{array}{l}\text { The question } \\
\text { in sequence. } \\
\text { Questionnair } \\
\text { e (2) }\end{array}$ & $\begin{array}{l}\text { Cronbach } \\
\text { alpha when } \\
\text { deleting }\end{array}$ & $\begin{array}{l}\text { The } \\
\text { variable }\end{array}$ & $\begin{array}{l}\text { The question } \\
\text { in sequence. } \\
\text { Questionnair } \\
\text { e (2) }\end{array}$ & $\begin{array}{c}\text { Cronbach alpha when } \\
\text { deleting }\end{array}$ \\
\hline Disciple & 1 & 0.995 & \multirow{8}{*}{$\begin{array}{c}\text { Independ } \\
\text { ent } \\
\text { variables }\end{array}$} & 9.) & 0.995 \\
\hline \multirow{7}{*}{$\begin{array}{c}\text { Variables } \\
\text { Independent }\end{array}$} & 2 & 0.995 & & 10.) & 0.995 \\
\hline & 3 & 0.994 & & & \\
\hline & 4 & 0.994 & & & \\
\hline & 5 & 0.994 & & & \\
\hline & 6 & 0.994 & & & \\
\hline & 7 & 0.994 & & & \\
\hline & 8 & 0.995 & & & \\
\hline
\end{tabular}

4- Data analysis and hypothesis testing: 
* Test the first hypothesis related to the dependent variable: "Iraqi banks are willing and able to finance leased projects." The dependent variable was measured by a single question addressed to the managers and financial officers of each bank, and possibly five answers according to the Likert scale.

The results of Table (12) show the approval of the managers and financial officials of Iraqi banks regarding their willingness and their ability to finance the leased projects according to the weighted average. The responses of the respondents showed that the most frequent answers were (fully agree) and 45 recurrences (47.9\%), And the arithmetic mean of the variable (4.18) was calculated by a standard deviation of 0.939 . This means accepting the hypothesis of the study of the willingness and ability of Iraqi banks to finance the leased projects.

Table (12): Direction of the sample answers about the willingness and ability of bank branches in leasing projects

\begin{tabular}{|c|c|c|c|c|c|c|c|}
\hline $\begin{array}{c}\text { Strongly } \\
\text { Agree }\end{array}$ & Agree & Neutral & Disagree & $\begin{array}{c}\text { Strongly } \\
\text { Disagree }\end{array}$ & mean & $\begin{array}{c}\text { Stander } \\
\text { division }\end{array}$ & Direction \\
\hline Iterations & Iterations & Iterations & Iterations & Iterations & & & \\
\hline 45 & $\%$ & $\%$ & $\%$ & $\%$ & & & \\
\hline 47.9 & 26 & 19 & 3. & 1. & 4.180 & 0.939 & \\
\hline & 27.7 & 20.2 & 3.2 & 1.1 & & & \\
\hline
\end{tabular}

Data analysis and testing of hypotheses related to independent variables: * data analysis

1: Knowledge of Iraqi banks and their knowledge of the activity of leasing as a source of funding for projects: This variable was measured by one question addressed to the study community. The results of Table 13 show that managers and accountants in Iraqi banks are familiar with the leasing activity as the source of project financing. Respondents' responses show that the most frequent answers are (29) This confirms that the weighted average of the variable is in the direction of approval and its mean (3.54) is a standard deviation $(1,341)$. 
The table (13) Direction of the sample answers About familiar branches of Iraqi banks and the familiarity with the activity of leasing

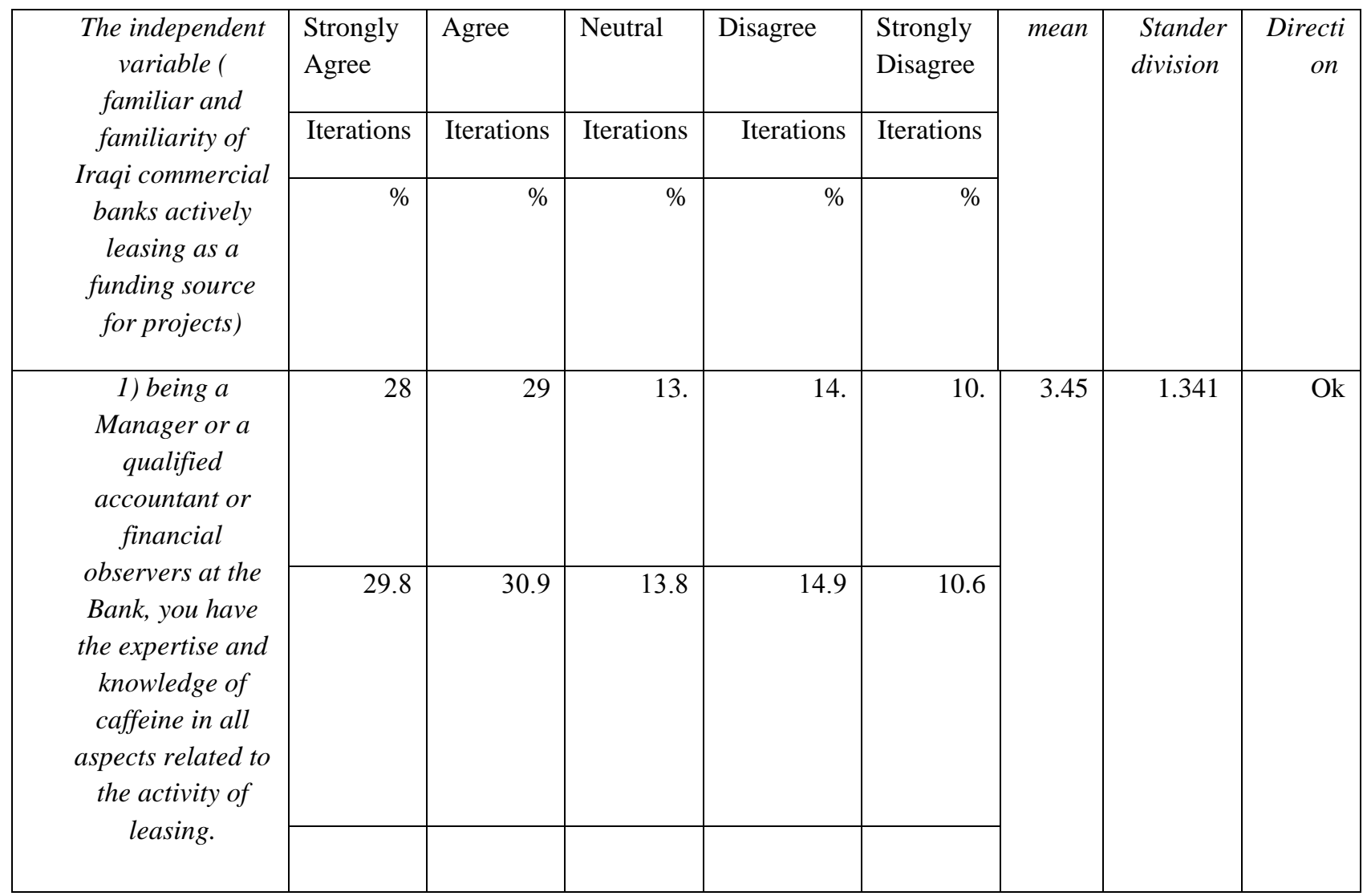

2: The flexibility of the leasing process:: This variable was measured by three factors, which were questions addressed to the study community. The results of the statistical analysis in Table (14) show the approval of Iraqi bank managers and their accountants according to the weighted average of the possibility of achieving the flexibility of the leasing by maintaining the leased assets from loading the tenant the risk of possession of the asset and maintenance and insurance costs. The average of the responses of the sample (4.03) and the standard deviation (1.031) 
Journal of University of Babylon, Pure and Applied Sciences, Vol.(27), No.(1): 2019

Table (14) Direction of the sample answers About flexible leasing process

\begin{tabular}{|c|c|c|c|c|c|c|c|c|}
\hline \multirow{3}{*}{$\begin{array}{c}\text { Independent } \\
\text { variable } v \\
\text { (flexible lease } \\
\text { process) }\end{array}$} & $\begin{array}{l}\text { Strongly } \\
\text { Agree }\end{array}$ & Agree & Neutral & Disagree & $\begin{array}{l}\text { Strongly } \\
\text { Disagree }\end{array}$ & mean & $\begin{array}{l}\text { Stander } \\
\text { division }\end{array}$ & \multirow{3}{*}{ Direction } \\
\hline & Iterations & Iterations & Iterations & Iterations & Iterations & & & \\
\hline & $\%$ & $\%$ & $\%$ & $\%$ & $\%$ & & & \\
\hline \multirow[b]{2}{*}{$\begin{array}{l}\text { 1) maintaining } \\
\text { leased assets by } \\
\text { loading the } \\
\text { tenant } \\
\text { paleasing } \\
\text { acquisition risk } \\
\text { and } \\
\text { maintenance } \\
\text { costs and } \\
\text { insurance. }\end{array}$} & 36 & 37 & 12. & 6. & 3. & \multirow[t]{2}{*}{4.03} & \multirow[t]{2}{*}{1.031} & \multirow[t]{2}{*}{ Ok } \\
\hline & 38.3 & 39.4 & 12.8 & 6.4 & 3.2 & & & \\
\hline \multirow[b]{2}{*}{$\begin{array}{l}\text { 2) To ensure an } \\
\text { investment asset } \\
\text { until the end of } \\
\text { the age by } \\
\text { contracted } \\
\text { economic } \\
\text { leasing again, } \\
\text { or by searching } \\
\text { for } \\
\text { opportunities to } \\
\text { leasing. }\end{array}$} & 33 & 40 & .5 & 10. & 6. & \multirow[t]{2}{*}{3.89} & \multirow[t]{2}{*}{1.187} & \multirow[t]{2}{*}{ Ok } \\
\hline & 35.1 & 42.6 & 5.3 & 10.6 & 6.4 & & & \\
\hline \multirow[b]{2}{*}{$\begin{array}{l}\text { 3) the } \\
\text { possibility of } \\
\text { choosing the } \\
\text { lessor lessee } \\
\text { which are } \\
\text { consistent with } \\
\text { the needs of the } \\
\text { service } \\
\text { provided to him } \\
\text { as a result of } \\
\text { the close link } \\
\text { between them } \\
\text { for great } \\
\text { flexibility } \\
\text { provided by the } \\
\text { contract. }\end{array}$} & 31 & 29 & .16 & 8. & 10. & \multirow[t]{2}{*}{3.67} & \multirow[t]{2}{*}{1.307} & \multirow[t]{2}{*}{ Ok } \\
\hline & 33 & 30.9 & .17 & 8.5 & 10.6 & & & \\
\hline
\end{tabular}


3: Banking Procedures and Laws: This variable was measured by three factors: questions addressed to the study population. It is clear from Table (15) that the managers and accountants of Iraqi banks confirm the possibility of banks to set up specialized companies affiliated to them through the investment law so that they enjoy the incentives and exemptions stipulated thereunder until a special law regulates the work of this activity and the relationship between the parties to the lease. (1.03). The managers of the Iraqi banks and their accountants also agree on the possibility of practicing the land and real estate activity, which was explained by the average of their responses (3.91) and by standard deviation (1.094). The researcher believes that this is done in banks Specialized especially agricultural and real estate bank, but are not subject to the customary tenancy laws in accordance with international standards. In the opinion of the researcher, there is a lack of consistency in these obstacles due to successive and continuous amendments to some of the previous relevant laws, which limit the Decision and expansion in another, in order to encourage investment in accordance with the cur leasing trends of the state.

Table (15): Direction of the sample answers About procedures and banking laws.

\begin{tabular}{|c|c|c|c|c|c|c|c|c|}
\hline \multirow{4}{*}{$\begin{array}{l}\text { Independent } \\
\text { variable vi } \\
\text { (procedures and } \\
\text { banking laws. ) }\end{array}$} & Strongly & Agree & Neutral & Disagree & Strongly & \multirow[t]{4}{*}{ mean } & \multirow{4}{*}{$\begin{array}{l}\text { Stander } \\
\text { division }\end{array}$} & \multirow{4}{*}{$\begin{array}{l}\text { Directi } \\
\text { on }\end{array}$} \\
\hline & & & & & & & & \\
\hline & Iterations & Iterations & Iterations & Iterations & Iterations & & & \\
\hline & $\%$ & $\%$ & $\%$ & $\%$ & $\%$ & & & \\
\hline \multirow{2}{*}{$\begin{array}{l}\text { 1) possibility in } \\
\text { creating specialized } \\
\text { companies leasing } \\
\text { appendage and } \\
\text { incentives and } \\
\text { exemptions enjoyed } \\
\text { by the investment } \\
\text { law. }\end{array}$} & 36 & 36 & .13 & 5. & 4. & \multirow{3}{*}{4.01} & \multirow{3}{*}{1.063} & \multirow{3}{*}{ OK } \\
\hline & 38.3 & 38.3 & 13.8 & 5.3 & 4.3 & & & \\
\hline \multirow{2}{*}{$\begin{array}{l}2 \text { The banks can } \\
\text { exercise) real estate } \\
\text { leasing activity. }\end{array}$} & 34 & 31 & 21 & 3. & 5. & & & \\
\hline & 36.2 & 33 & 22.3 & 3.2 & 5.3 & 3.91 & 1.094 & OK \\
\hline \multirow{2}{*}{$\begin{array}{l}\text { 3) absence of legal } \\
\text { impediments to the } \\
\text { exercise of } \\
\text { commercial banks } \\
\text { activity of leasing. }\end{array}$} & 22 & 19 & 29 & 9. & 15. & \multirow[t]{2}{*}{3.26} & \multirow[t]{2}{*}{1.352} & \multirow[t]{2}{*}{ Neutral } \\
\hline & 23.4 & 20.2 & 30.9 & 9.6 & 16. & & & \\
\hline
\end{tabular}

4: Project Commitments to the Bank in Asset Finance: This variable was measured by two factors that were two face-to-face questions to the study community. It is clear from Table (16) that the full approval of the managers of the Iraqi banks and their accountants is based on the ability of the lessor to seize the assets as the legal owner 
of them. This leads to the sure certainty of the lessor in collecting the payments made by the lessee by means of the arithmetic average of the answers of the sample members (4.33) 1.051), as well as the consent of the lessor to retain the ownership of the asset and its recoverability ty when the lessee breached the terms of the contract and not to pay the remaining payments indicated by the average responses of the sample members (4.15) and by standard deviation (1.005).

\section{Table (16):Direction of the sample answers About project undertakings towards the Bank to finance its assets}

\begin{tabular}{|c|c|c|c|c|c|c|c|c|}
\hline \multirow{2}{*}{$\begin{array}{l}\text { Independent variable VII } \\
\text { (project undertakings } \\
\text { towards the Bank in asset } \\
\text { financing) }\end{array}$} & $\begin{array}{l}\text { Strongly } \\
\text { Aoree }\end{array}$ & Agree & Neutral & Disagree & Strongly & \multirow[t]{2}{*}{ mean } & \multirow{2}{*}{$\begin{array}{l}\text { Stander } \\
\text { division }\end{array}$} & \multirow[t]{2}{*}{ Direction } \\
\hline & Iterations & Iterations & Iterations & Iterations & Iterations & & & \\
\hline \multirow{2}{*}{$\begin{array}{l}\text { 1. leased capacity on } \\
\text { reserve assets being the } \\
\text { legal owner of her } \\
\text { leading to the surest } \\
\text { guarantee for the lessor } \\
\text { to the lessee owes } \\
\text { collection batches. }\end{array}$} & 54 & 30 & .2 & 3. & 5. & \multirow{3}{*}{4.33} & \multirow{3}{*}{1.051} & \multirow{3}{*}{$\begin{array}{l}\text { Quite } \\
\text { OK }\end{array}$} \\
\hline & 57.4 & 31.9 & 2.1 & 3.2 & 5.3 & & & \\
\hline \multirow{2}{*}{$\begin{array}{l}2 \text { The lessor retains the } \\
\text { original ownership) and } \\
\text { the possibility of it back } \\
\text { when the tenant's breach } \\
\text { of contract and not } \\
\text { committed to the } \\
\text { remaining payments }\end{array}$} & 54 & 30 & .2 & 3. & 5. & & & \\
\hline & 57.4 & 31.9 & 2.1 & 3.2 & 5.3 & 4.15 & 1.051 & $\mathrm{OK}$ \\
\hline
\end{tabular}

\section{* Test the second hypothesis:}

There is a relationship of statistical significance between the knowledge of Iraqi banks and their knowledge of the leasing activity and its desire and ability to provide financing for leasing projects." In order to test the validity of this hypothesis, the correlation coefficient and the coefficient of selection were measured between the independent variable and the dependent variable. The results in Table 17 show that the expertise of the Iraqi banks and their knowledge of the activity is strongly related to their willingness and ability to finance the leased projects, $(56.2 \%)$, which indicates that the independent variable can explain the equivalent of $(56.2 \%)$ of the change in the willingness of the Iraqi banks and their ability to finance the leased projects, that is, the independent variable has a strong impact on The dependent variable.

The table also shows that the value of the regression coefficient for Iraqi banks' knowledge and their knowledge of the leasing activity (0.525). This means that the change in the amount of one unit in the knowledge of the Iraqi banks and their knowledge of the leasing activity will lead to a change in the desire of these banks and their ability to finance the leased projects by $(0.525)$ The value of $(t)$ calculated 
for the regression coefficient value of this variable (10.866), which is larger than the scale (2.633) and at a significant level (1\%). The effect of the statistical significance of the Iraqi banks' knowledge and their knowledge of the leasing activity, With a relationship (118.063) is greater than the scale (6.92) at a significant level (1\%) and the degree of freedom (the percentage) 1/92).

Table (17): The results link relationships and regression according to respondents answer About the relationship of knowledgeable Iraqi bank branches and the familiarity with the activity of leasing with her desire and ability in project finance-leased

\begin{tabular}{|l|l|l|l|l|l|l|}
\hline REGRESSION & \multicolumn{2}{|l|}{ TEST T } & R2 & $\mathrm{R}$ & \multicolumn{2}{l|}{ TEST F } \\
\cline { 5 - 7 } \\
\cline { 2 - 6 } & $\begin{array}{l}\text { COlculated } \\
*\end{array}$ & Crosstab & & & $\begin{array}{l}\text { Calculated } \\
*\end{array}$ & Crosstab \\
\hline 0.525 & 10.866 & 2.633 & $56.2 \%$ & $75 \%$ & 118.063 & 6.92 \\
\hline
\end{tabular}

* The moral level $1 \%$

*Test the third hypothesis:"There is a relationship of statistical significance between the flexibility of the process of leasing and the desire of Iraqi banks and their ability to provide financing for leasing projects." In order to test the validity of this hypothesis, the correlation coefficient and the coefficient of selection were measured between the independent variable and the dependent variable. The results in Table (18) show that the flexibility of the lease process has a strong relationship with the willingness of the Iraqi banks and their ability to finance the leased projects (R) $77.9 \%$ ), while the limiting factor (R2) (60.7\%), ie, the independent variable has a strong impact on the dependent variable. The value of the regression coefficient for this variable $(11,930)$, which is larger than the scale (2.633) and at a significant level (1\%), is indicated by the effect of the statistical significance of the flexibility of the lease process on The desire of the Iraqi banks and their ability to finance the leased projects. Thus, the hypothesis of the study was accepted with a statistically significant relationship between the flexibility of the lease process and the willingness of the Iraqi banks and their ability to finance the leased projects. The results of this test confirm their statistical acceptance; the calculated (142.318) (6.92) at a significant level (1\%) and the degree of freedom (1/92). 
Table (18): The results link relationships and regression according to respondents answer About the relationship of the flexibility of the process of lease with the desire and ability of bank branches in leasing projects

\begin{tabular}{|r|l|l|l|l|l|l|}
\hline $\begin{array}{r}\text { Regression } \\
\text { coefficient }\end{array}$ & \multicolumn{2}{|l|}{ Test $t$} & $R 2$ & $R$ & \multicolumn{2}{l|}{ Test $F$} \\
\cline { 2 - 7 } \\
\cline { 2 - 7 } & $\begin{array}{l}\text { Calculated } \\
*\end{array}$ & Crosstab & & & & \\
\cline { 5 - 7 } & 11.930 & 2.633 & $60.7 \%$ & $77.9 \%$ & 142.318 & 6.92 \\
& & & & & & \\
\hline
\end{tabular}

* The moral level 1\%

* Test the fourth hypothesis: "There is a significant statistical relationship between banking procedures and laws and the desire of Iraqi banks and their ability to provide financing for leasing projects." The results in Table (19) show that banking procedures and laws have a strong relationship with the desire of the Iraqi banks and their ability to finance the leased projects as indicated by the correlation coefficient (R) $(76.9 \%)$. The (R2) (59.1\% (0.640). The value of (t) calculated for the regression coefficient value of this variable (11.525), which is larger than the tabular (2.633) and at a significant level (1\%), indicates the existence of the effect The significance of statistical procedures and banking laws on the desire of Iraqi banks and their ability In the financing of the leased projects. Thus, the hypothesis of the study was accepted with a statistically significant relationship between the banking procedures and laws and the desire of the Iraqi banks and their ability to finance the leased projects. At a significant level (1\%) and freedom degree (1/92).

Table (19) The results link relationships and regression as A Respondents answer About actions and relationship banking laws with the desire and ability of bank branches in leasing projects

\begin{tabular}{|r|l|l|l|l|l|l|}
\hline $\begin{array}{r}\text { Regression } \\
\text { coefficient }\end{array}$ & \multicolumn{2}{|l|}{ Test $t$} & $R 2$ & $R$ & \multicolumn{2}{l|}{ Test $F$} \\
\cline { 2 - 7 } & $\begin{array}{l}\text { Calculated } \\
*\end{array}$ & Crosstab & & & & \\
\cline { 5 - 7 } & & & & & & \\
$* .640$ & 11.525 & 2.633 & $59.1 \%$ & $76.9 \%$ & 132.826 & 6.92 \\
\hline
\end{tabular}

* The moral level $1 \%$

*Test the fifth hypothesis: "There is a statistically significant relationship between the project's commitments to the bank in financing the assets and the desire of the Iraqi banks and their ability to provide financing for the leasing projects."

The results in Table (20) show that the project's commitments to the bank to finance the assets have a strong relationship with the willingness of the Iraqi banks and their ability to finance the leased projects as indicated by the correlation coefficient $(56.4 \%)$, indicating that the independent variable has a strong effect on the 
dependent variable. The table also shows that the value of the regression coefficient for the project commitments towards the bank in financing the assets (0.712) (t) calculated for the regression coefficient value of this variable (11.017) and (2.633) and at a significant level $(1 \%)$ with the effect of the statistical significance of the project's undertakings towards the bank in financing assets on the willingness of the Iraqi banks and their ability to finance the leased projects. In the financing of assets and the desire of Iraqi banks and their ability to finance the leased projects, which confirms the results of the test F acceptance of statistical; the calculated (121.343) greater than the table (6.92) at the level of moral (1\%) and degree of freedom (1/92).

The table (20): The results link relationships and regression according to respondents answer About the relationship of project undertakings towards the Bank in asset financing with the desire and ability of bank branches in leasing projects

\begin{tabular}{|c|c|c|c|c|c|c|}
\hline \multirow[b]{2}{*}{$\begin{array}{l}\text { Regression } \\
\text { coefficient }\end{array}$} & \multicolumn{2}{|l|}{ Test $t$} & \multirow[t]{2}{*}{$R 2$} & \multirow[t]{2}{*}{$R$} & \multicolumn{2}{|l|}{ Test $F$} \\
\hline & $\begin{array}{l}\text { Calculated } \\
*\end{array}$ & Crosstab & & & $\begin{array}{l}\text { Calculated } \\
*\end{array}$ & Crosstab \\
\hline 0.712 & 11.017 & 2.633 & $56.9 \%$ & $75.4 \%$ & 121.343 & 6.92 \\
\hline
\end{tabular}

*The moral level $1 \%$

\section{- Section Four: Conclusions and Recommendations}

\section{Conclusions:}

At the end of this study, the researcher reached a number of conclusions.

1. The absence of a legislative framework that regulates and governs the exercise of the leasing decision in Iraq.

2. Banks are concerned about this financing formula in terms of return and risk.

3. The field study of Iraqi projects proved the following:

(A) the willingness and ability of the enterprises to engage in the leasing activity;

(B)The presence of a statistically significant relationship between the knowledge of the project and its knowledge of the leasing activity and the flexibility of the lease process, the commitments of the leased project against the financing of its assets on the one hand, and the desirability of the projects and their ability to exercise the leasing activity on the other.

4.The field study proved to the Iraqi banks:

A) the willingness of banks and their ability to provide financing for leasing projects.

B) The existence of a statistically significant relationship between the knowledge of the Iraqi banks and their knowledge of the leasing activity, the flexibility of the leasing process, the banking procedures and laws, the commitments of the leased project towards the bank in financing its assets and the willingness of Iraqi banks and their ability to provide finance for leasing projects. 


\section{Recommendations}

According to the conclusions of the study, the researcher recommends the following:

1- $\quad$ Urge the Iraqi legislator to expedite the legislation of the legal and tax laws governing the work of the leasing activity, by forming a joint scientific committee with the competence and experience in finance, accounting, law and university professors to determine the financial and accounting principles and rules that should be taken in the activity based on the financial accounting standards International.

2- Encouraging the investment by allowing the Iraqi banks to establish the financial companies through the investment law and benefiting from the expertise and competencies of the foreign companies that are engaged in the leasing activity to introduce the country's advanced technology.

3- To create an economic and legal environment; to create a favorable climate for the development of leasing and to pay particular attention to it.

4- Direct and indirect government support, whether it is related to the financial or moral aspect of this formula, and follow up its application to ensure the permanent and continuous adaptation of this funding formula with all that is new and ensure its success.

\section{CONFLICT OF INTERESTS.}

There are non-conflicts of interest.

\section{The References}

1- Scholz . peter, " Leasing : A financing Alternative for SMEs? ", A university Thesis Presented to the Faculty of IMADEC University , August , 2007

2- Shiha, Mustafa,(2001), "Economic Construction of the Project", Alexandria

3- Stewart C. Myers, Principles of corporate finance, Boston, Mass: McG. Hill / Irwin , 2003

4- Giacotto, Carmelo, Goldeberg, Gerson and Hegde Shantaram, " The Value of Embedded Real Options : Evidence from Consumer Automobile Lease Contracts ", The Journal of Finance 62, 2007

5- Hussein, Shawky, (2003),"Finance and Financial Management", Cairo, 1986.

6- Choudhry, Moorad. An introduction to value -at -risk . 4th ed . Chichester . John Wiley \& Sons Ltd ,.2006

7- Tawfiq, Jamil; Sharif, Ali,(2006), "Financial Management", Cairo,.

8- Fabozzi, Frank J . \& Peterson, Pamela P., Financial management and analysis, John Wily \& Sons Inc, Second Edition , 2003

9- Mokhtar, Ibrahim, (2006),"Banking Finance", Cairo,.

10- El-Tohamy, Abdel-Moneim,(2004), "Financing Introduction to Financial Institutions and Markets", Cairo,.

11- Olsson Karl O.\& Olsson " Finansiering " Sweden Goteborgs Universitet . Magnus , 2006

12- Smart and Megginson , "Introduction To Financial Management " $2^{\text {nd }}$ Edition , 2008

13- - Thomas, et al, Intermediate Accounting ",, $5^{\text {th }}$ Edition , New York, Irwin , Mc Graw - Hill , 2001 
14- - Hendel I., and A. Lizzeri , "The Role of Leasing Under Adverse Selection ", Journal of Political Economy 110, 2002

15- - KPMG . " Risiken \& Risiko management bie Leasing gesells chaften . " KPMG Vienna March 7,2007

16- Ei-Bey, (2010),"Credit bail mobilier", P.U.F., QueSaisje

\section{الخلاصة}

ان التكنولوجيا الحديثة لتمويل الاستثمارات، والتأجير، اخذت اهتمام واسع في البلدان الصناعية بسبب مرونتها الخاصة،

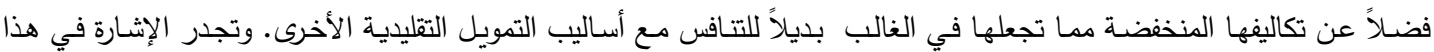
الصدد إلى أن البلدان النامية بثكل عام والعربية خصوصا في الغالب ما زالت متأخرة نسبياً في تطبيق هذا النوع من التمويل، فإن الناليال شركات التأجير لا تزال منخفضـة جداً مقارنة بالبلدان الصناعية بسبب أسـاليب التحكم التقليدية في تمويلها. المؤسسات المالية، ومخاطر عدم القبول في مجالات التمويل الجديدة، ونقص الاحتراف في المجال المالي والدصرفي ثم التهرب من المشاركة النشطة نسبياً في التمية الاقتصادية؛ تتاولت هذه الدراسة قرارات التأجير في البيئة العراقية كمصدر تمويل للمشاريع لتحديد مدى رغبة المشاريع العراقية وقدرتها على ممارسة نثاط التأجير ، وكذلك رغبة البنوك العراقية وقدرتها على تمويل باستعمال التأجير ـ ولكي يتم الاجابة على الفرضيات التي تناولتها الدراسة حيث تم بناء استمارة استبيان بالاعتماد على مقياس ليكرت الخماسي وتم توزيعها

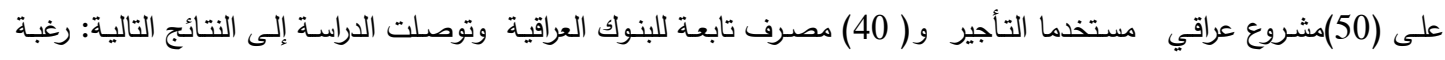

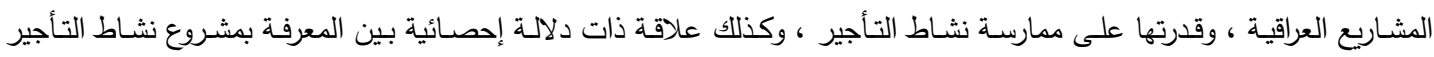

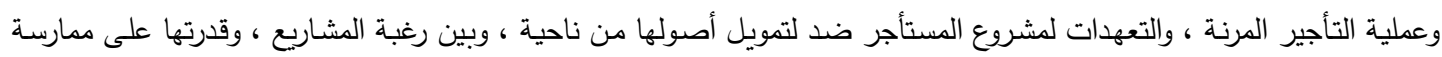

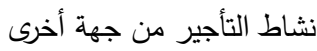

